DOI: 10.46340/eujem.2020.6.5.8

Oksana Kharchenko

ORCID ID: https://orcid.org/ 0000-0003-1162-1681

O.M. Beketov National University of Urban Economy in Kharkiv, Ukraine

\title{
SPATIAL DIFFERENTIATION OF TOURIST TRAFFIC IN THE REGIONS OF UKRAINE
}

\author{
Оксана Харченко \\ Україна

\section{ПРОСТОРОВА ДИФЕРЕНЦАЦІЯ ТУРИСТИЧНОГО РУХУ В РЕГІОНАХ УКРАЇНИ}

Харківський національний університет міського господарства імені О. М. Бекетова,

The article examines the theoretical and methodological foundations of spatial differentiation in the tourism activities of the regions of Ukraine. It was found that the problem of domestic and foreign tourism in the regions of Ukraine should stimulate economic and social growth in depressed, unfavorable for industrial and agricultural production regions, reduce the migration of the population of these regions to large cities and industrial centers. The analysis of basic research of conceptual bases of essence of categories "spatial differentiation" is carried out and its generalized author's definition is given. The analysis of tourist traffic both in Ukraine and by individual regions is given and it is revealed that the problem of uneven spatial distribution of tourist resources in the regions of Ukraine is significant. The mechanism of effective management of tourist activity as a tool for overcoming spatial differentiation on uneven distribution of tourist resources of regions of Ukraine is developed.

Keywords: mechanism, spatial differentiation, tourist services, tourist market, tourist movement.

Постановка проблеми в загальному виді. На сучасному етапі розвитку України набувають особливої актуальності питання створення ефективної структури управління туристичною галуззю у сфері підвищення загального та локального туристичного руху. Україна як туристична держава світового значення вимагає усестороннього забезпечення координації діяльності різноманітних сфер економіки, від яких залежить якісне та надійне надання туристичних послуг, а саме: торгівлі, транспорту, видавничо-рекламної діяльності, виробництва сувенірної продукції тощо. Сьогодні туризм $\epsilon$ перспективною та неповно використаною галуззю для економіки України, а отже одним із пріоритетних напрямків її розвитку.

Таким чином, проблема розвитку внутрішнього та зовнішнього туристичного руху у регіонах України повинна стимулювати економічне та соціальне зростання в депресивних, несприятливих для промислового та сільськогосподарського виробництва регіонах, сприяти зменшенню міграції населення цих регіонів до великих міст і промислових центрів. Тому проблема просторової диференціації туристичного руху урегіонах України $є$ актуальною темою дослідження та має практичну значущість як для окремого регіону, так й для державі в цілому.

Аналіз останніх досліджень і публікацій. Проблематикою просторової диференціації у туристичній галузі успішно займалися наступні вчені, а саме: Рега М.В., Паршин Ю.І., Экова В.А., Шкромада В.И., Сорока І.В., Тарасенок А.И., Зиновьева А.А., Кругман П. Р. та інші.

Однак слід зауважити, що недостатність аналізу процесів просторової диференціації туристсько-рекреаційного потенціалу інфраструктури туризму, особливо це стосується розгляду проблем регіонального туризму не $\epsilon$ достатньо дослідженим. Тому постає нагальне питання теоретичного та практичного вирішення означеної проблеми за допомогою сучасних методичних підходів та інноваційних засобів, які використовуються у дослідженнях ринку туристичних послуг.

Мета роботи. Мета полягає у дослідженні просторової диференціації туристичного руху в мінливих умовах сучасного розвитку туристичної галузі регіонів України. 
Виклад основного матеріалу дослідження. В сучасних умовах нагальної необхідності трансформації структури економіки України все більшого значення набуває туристична галузь як інструмент сталого фінансово-економічного зростання господарства шляхом прямого та опосередкованого стимулювання економіки з метою збільшення обсягів надання послуг та вироблення додаткової вартості. Активний туристичний рух є запорукою сталого зростання всієї туристичної галузі та суцільно пов'язаний з ефективністю та широтою ринку туристичних послуг, який у процесі свого розвитку проходить чотири стадії розвитку (початкову, накопичувальну, консолідації та модернізації). Тому доцільно дослідити вплив туристичного руху на розвиток туристичного ринку України (рис. 1).

Треба відзначити, що управління розвитком ринку туристичних послуг на кожній стадії відбувається на основах взаємодії загальнодержавних та локально-ринкових напрямів впливу, що $є$ нагально необхідним та доцільним, з огляду на постійну наявність напрямів, реалізація яких знаходиться поза компетенцією самих суб'єктів ринку. Тривалість кожного етапу не визначено та залежить у своїй більшості від типу ринку регіону, наявності та якості внутрішніх та зовнішніх факторів, ступеня туристичного руху того чи іншого регіону, постійному моніторингу можливостей та загроз, які постійно виникають під час туристичного руху на ринку туристичних послуг.

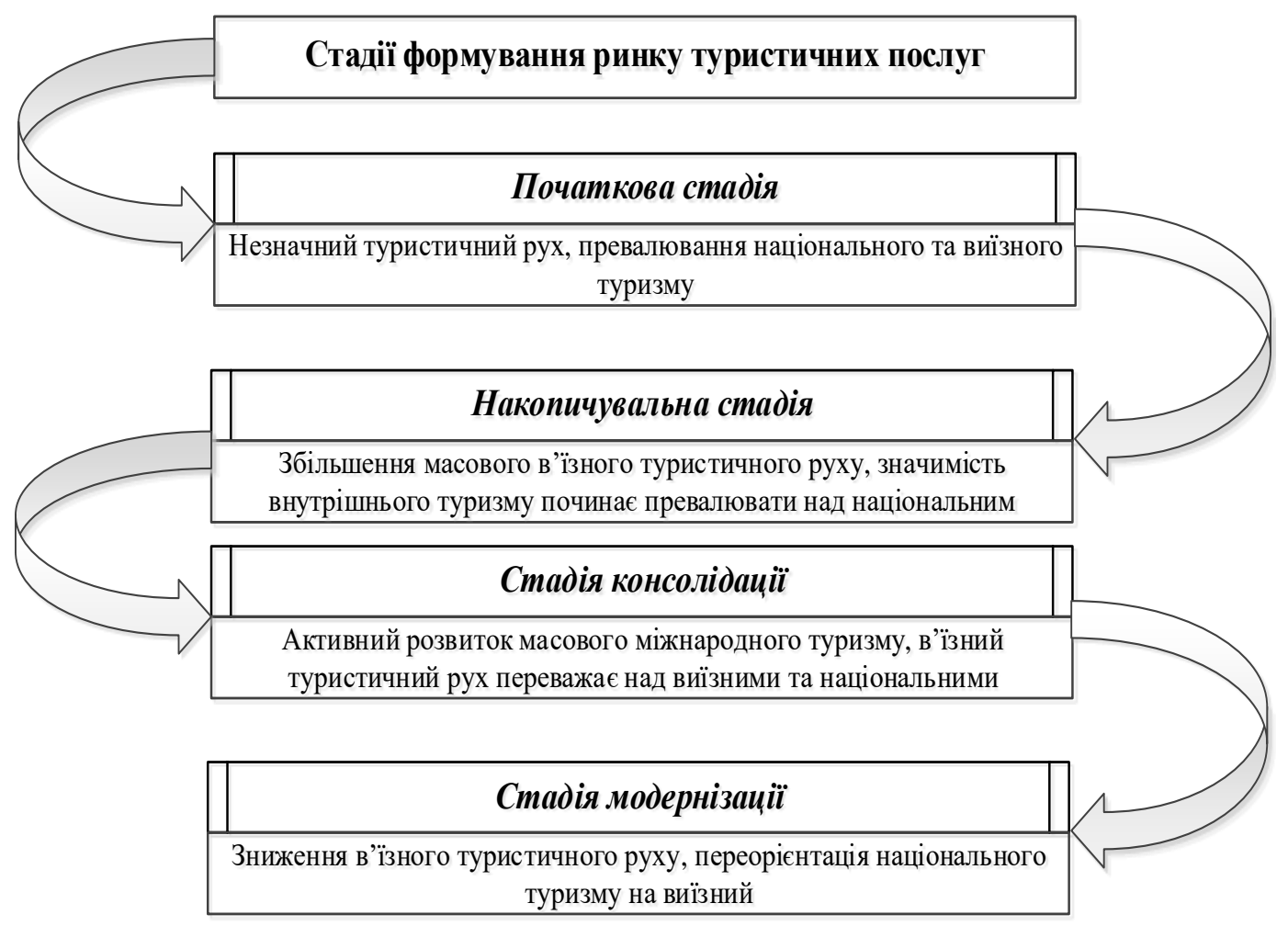

\section{Рис. 1. Туристичний рух на різних стадія розвитку ринку туристичних послуг ${ }^{1}$}

Стадії розвитку ринку туристичних послуг як окремого регіону, так й України в цілому $є$ загальним фактором та не завжди визначальним впливу на туристичний рух населення. У дослідженні цього питання більшої уваги заслуговує туристичний, економічний та соціальний розвиток кожного регіону України - це є об’єктивною умовою розвитку туристичного ринку. Нерівномірний туристичний розподіл регіонів викликаний наступними факторами:

- значними відмінностями в кількості та доступності природних ресурсів;

- кліматичними особливостями;

- культурно-історичною спадщиною

\footnotetext{
${ }^{1}$ Сорока, I. В. (2012). Сучасні тенденції міжнародного ринку туристичних послуг. Актуальні проблеми міжнародних відносин, 111, 266-273.
} 
- нерівномірністю розміщення інфраструктури, а саме: транспортної, комунікаційної, курортно-розважальної

- асиметричністю розподілу рекреаційних ресурсів регіонів тощо.

У зв'язку з вищенаведеним питання розвитку туристичного руху з урахуванням диференційних аспектів просторового розвитку набувають все більшої актуальності. Тому необхідно визначити науково-теоретичний сенс поняття просторова диференціація та надати комплексне загальне визначення для ефективності подальшого практичного дослідження.

Розвиток туристичного руху в умовах просторової диференціації часто характеризується наявністю наступних взаємопов'язаних тенденцій:

- значному впливу факторів та ресурсів на суб'єктів ринку

- розповсюдження активного впливу факторів та ресурсів на місце свого функціонування.

Зазначимо, що у широкому сенсі під просторово-диференційними факторами впливу туристичний рух прийнято розуміти усю сукупність факторів зовнішнього середовища, притаманних певному середовищу, полюсу росту - територіальному, інформаційному, ресурсному, інституційному тощо ${ }^{1}$.

Зазначимо, що для успішності практичних досліджень необхідно узагальнити и систематизувати дефініцію категорії «просторова диференціація» як загальноекономічне поняття, так й для туристичної галузі.

Паршин Ю.І. вважає, що просторова диференціація - це нерівномірність економічного розвитку, що виникла внаслідок процесу нерівномірного перерозподілу економічних ресурсів, доходів і витрат, яка виражається на різних рівнях соціально-економічного й екологічного розвитку 2.

Екова В.А. також наполягає, що під просторовою диференціацією можна розуміти стан, що відбиває певну сукупність розподілу ресурсів природно-господарської і соціально-економічної системи, для даної території в певний момент часу ${ }^{3}$.

3 іншого боку, Шкромада В.І. наполягає, що просторова диференціація, перш за все, це сукупність характеристик рівнів розвитку регіонів, які формуються дією базових чинників, а також їх динамічних тенденцій під дією актуальних чинників, що обумовлюють структурні зміни по виробничо-економічним, фінансово-економічним і соціально-економічним напрямкам ${ }^{4}$. Також заслуговує на увагу визначення категорії «просторова диференціація», що надано Сорокою І.В., а саме: поляризація економічного простору обумовлює концентрацію трансакцій, що забезпечують створення, поширення i застосування знань в точках зростання i ініціацію нерівноважного, нелінійного процесу самоорганізації інноваційних відносин як складної системи, в рамках якої інновація як продукт і як процес трансформується в напрямку формування «інновацій в інноваціях» 5 .

Тарасенок А.І. розглядає категорію «просторова диференціація» світової туристичної галузі як об'єктивний процес формування світових центрів і зон з різним рівнем концентрації туристичного попиту, капіталу та інновацій в туристичному комплексі» ${ }^{3}$. Зинов'єва А.А. у своєї статті дає висновок, що просторова диференціація - це наслідок прямої пропорційної залежності між економічними вигодами, які отримуються від продажу туристичного продукту, і зростанням рівня конкуренції.

Особливої уваги заслуговує наукові дослідження Кругмана П. у яких він виділяє два основних типи територіальної організації економічного простору: більш розвинене ядро («центр») і тісно

\footnotetext{
${ }^{1}$ Рега, М. В. (2009). Туристичний бізнес в економічному просторі України. Теоретичні та прикладні питання економіки, 19, 299-303.

${ }^{2}$ Паршин, Ю. І. (2014). Оцінка нерівномірності економічного розвитку за індикаторами поляризації та асиметрії. Інвестииіі: практика та досвід, 24, 28-33.

3 Экова, В. А. (2013). Идентификация объектов пространственного менеджмента в регионе. Материаль международной научно-практической конференции «Современные направления теоретических и прикладных исследований. 2013» <http://www.sworld.com.ua/index. php/uk/economy-113/where-to-stay-productive-forces-andregional-economy-113/ 16975-113-0762>(2020, вересень, 15).

${ }^{4}$ Шкромада, В. И. (2013). Совершенствование налоговых инструментов сглаживания социально-экономической поляризации регионов : автореферат диссертации на соискание научной степени кандидата экономических наук. Белгород: ФГАОУ ВПО Белгородский государственный национальный исследовательский университет. ${ }^{5}$ Сорока, I. В. (2012). Сучасні тенденції міжнародного ринку туристичних послуг. Актуальні проблеми міжнародних відносин, 111, 266-273.

${ }^{6}$ Тарасенок, А. И. (2014). Геоэкономический механизм обеспечения конкурентоспособности туристической дестинации. Минск: РИПО, 144.
} 
пов’язана з ним «периферія». «Центр» - це локальний ринок, у нашому випадку регіон, де виникає та зосереджується туристичний рух, перенаправляються в'їзні туристичні потоки, знаходиться велика концентрація природно-рекреаційних, культурно-історичних ресурсів, активно та ефективно розвивається туристична та супутня інфраструктура, розміщуються великі міжнародні готельні та ресторанні мережі, закладені раціональні стандарти обслуговування та створення комплексного туристичного продукту, які у процесі просторової диференціації поширюються на «периферію», тобто на регіони з меншою ємністю туристичного ринку ${ }^{1}$.

Таким чином, можна зробити висновок, що просторова диференціація у галузі туризму - це нерівномірність розвитку ринку туристичних послуг, яку викликано значимими відмінностями в розподілі природних ресурсів, кліматичними особливостями регіонів, культурно-історичною обумовленістю міст та областей, нерівномірним розміщенням транспортної, комунікаційної, курортно-розважальної інфраструктури та диспропорцією розподілу рекреаційних ресурсів.

Туристичний потенціал України за умов його ефективного впровадження та використання спроможний забезпечити виконання економічних, соціальних, гуманітарних функцій держави, тобто підвищити рівень життя населення, збільшити частку туристичних надходжень до бюджетів усіх рівнів, збільшити кількість робочих місць в туристичній сфері та супутніх галузях тощо.

Динаміка та структура в 'їзного та виїзного туристичного руху України протягом 2000-2019 pp. показано в таблиці 1.

3 таблиці 1 видно, що 2018-2019 рр. характеризуються збільшенням загального показника туристичного руху в порівнянні з іншими роками статистичної вибірки. Треба також відзначити, що до 2009 року найбільшу частку (50-60 \%) туристичного руху України складав внутрішній туризм. Ця тенденція є прямим наслідком нестачі грошових коштів та заощаджень у населення України та бажання вивчати туристично-рекреаційні об'єкти рідної Вітчизни. В ці ж роки зафіксовано найбільшу питому вагу (15-20 \%) іноземних туристів, що в 'їджали та користувалися туристичними ресурсами України.

Після 2010 року спостерігається постійне стійке зростання виїзного туризму, та значне зменшення інших видів туристичного руху. Причини такої тенденції наступні:

- тимчасово недоступний туризм у Автономну Республіку Крим, м. Севастополь та на тимчасово окупованих територій у Донецькій та Луганській областях;

- нерозвиненість у більшості регіонах України туристично-рекреаційних зон та відсутність там сервісу європейського рівня;

- бажання населення України відкривати нові туристичні маршрути;

- збільшення заощаджень та наявних грошових коштів для відпочинку за межами України.

Для детального дослідження та аналізу наявності та розподілу просторової диференціації туристичного руху України, перш за все, треба розглянути статистичну інформацію щодо туристичного руху за регіонами у 2019 р. (табл. 2).

Підвищення ефективності функціонування суб'єктів ринку туристичних послуг регіонів України дозволить згладити просторову диференціацію туристичного руху. Для цього необхідно розробити універсальний та дієвий механізм з урахуванням специфічних особливостей регіонів, задіяності більшої кількості суб'єктів інфраструктури туризму у створені якісного туристичного продукту та використання багатої історично-культурної спадщині регіонів України для підвищення туристичного руху периферійних областей при збереженні показників «Центру».

Основою реалізації механізму повинно бути врахування просторової складової диференціації регіонів України, яка впливає на умови функціонування суб'єктів туристичного ринку у наявному географічному та економічному просторі, створює базис для стратегічного розвитку туризму. Нормативно-правовою основою формування механізму щодо ефективізації туристичних послуг $\epsilon$ Закони України, підзаконні акти, нормативні документи зі стандартизації й сертифікації у сфері туризму.

Розробимо механізм ефективного управління туристичною діяльністю щодо подолання просторової диференціації на нерівномірності розвитку туристично-рекреаційних послуг регіонів України, у якому врахуємо результати проведеного аналізу туристичного руху, зазначимо суб'єкт, об'єкт та мету управління туристичним розвитком регіонів (рис. 2).

\footnotetext{
${ }^{1}$ Krugman, P. (1991) Geography and Trade. Cambridge: MA: MIT Press.
} 
Таблиця 1

Динаміка та структура туристичного руху України за 2000-2019 рp. 1)

\begin{tabular}{|c|c|c|c|c|c|c|c|}
\hline \multirow[b]{2}{*}{ Роки } & \multirow{2}{*}{$\begin{array}{c}\text { Кількість туристів, } \\
\text { обслугованих } \\
\text { туроператорами } \\
\text { та турагентами, } \\
\text { усього осіб }\end{array}$} & \multicolumn{3}{|c|}{ У тому числі } & \multicolumn{3}{|c|}{ Структура туристичного руху } \\
\hline & & $\begin{array}{c}\text { в'їзні } \\
\text { (іноземні) } \\
\text { туристи, } \\
\text { осіб }\end{array}$ & $\begin{array}{l}\text { виїзні } \\
\text { туристи, } \\
\text { осіб }\end{array}$ & $\begin{array}{l}\text { внутрішні } \\
\text { туристи, } \\
\text { осіб }\end{array}$ & $\begin{array}{c}\text { в'їзні } \\
\text { (іноземні) } \\
\text { туристи, } \\
\text { осіб }\end{array}$ & $\begin{array}{l}\text { виїзні } \\
\text { туристи, } \\
\text { осіб }\end{array}$ & $\begin{array}{l}\text { внутрішні } \\
\text { туристи, } \\
\text { осіб }\end{array}$ \\
\hline 2000 & 2013998 & 377871 & 285353 & 1350774 & $18,76 \%$ & $14,17 \%$ & $67,07 \%$ \\
\hline 2001 & 2175090 & 416186 & 271281 & 1487623 & $19,13 \%$ & $12,47 \%$ & $68,39 \%$ \\
\hline 2002 & 2265317 & 417729 & 302632 & 1544956 & $18,44 \%$ & $13,36 \%$ & $68,20 \%$ \\
\hline 2003 & 2856983 & 590641 & 344332 & 1922010 & $20,67 \%$ & $12,05 \%$ & $67,27 \%$ \\
\hline 2004 & 1890370 & 436311 & 441798 & 1012261 & $23,08 \%$ & $23,37 \%$ & $53,55 \%$ \\
\hline 2005 & 1825649 & 326389 & 566942 & 932318 & $17,88 \%$ & $31,05 \%$ & $51,07 \%$ \\
\hline 2006 & 2206498 & 299125 & 868228 & 1039145 & $13,56 \%$ & $39,35 \%$ & $47,09 \%$ \\
\hline 2007 & 2863820 & 372455 & 336049 & 2155316 & $13,01 \%$ & $11,73 \%$ & $75,26 \%$ \\
\hline 2008 & 3041655 & 372752 & 1282023 & 1386880 & $12,25 \%$ & $42,15 \%$ & $45,60 \%$ \\
\hline 2009 & 2290097 & 282287 & 913640 & 1094170 & $12,33 \%$ & $39,90 \%$ & $47,78 \%$ \\
\hline 2010 & 2280757 & 335835 & 1295623 & 649299 & $14,72 \%$ & $56,81 \%$ & $28,47 \%$ \\
\hline 2011 & 2199977 & 234271 & 1250068 & 715638 & $10,65 \%$ & $56,82 \%$ & $32,53 \%$ \\
\hline 2012 & 3000696 & 270064 & 1956662 & 773970 & $9,00 \%$ & $65,21 \%$ & $25,79 \%$ \\
\hline 2013 & 3454316 & 232311 & 2519390 & 702615 & $6,73 \%$ & $72,93 \%$ & $20,34 \%$ \\
\hline 2014 & 2425089 & 17070 & 2085273 & 322746 & $0,70 \%$ & $85,99 \%$ & $13,31 \%$ \\
\hline 2015 & 2019576 & 15159 & 1647390 & 357027 & $0,75 \%$ & $81,57 \%$ & $17,68 \%$ \\
\hline 2016 & 2549606 & 35071 & 2060974 & 453561 & $1,38 \%$ & $80,83 \%$ & $17,79 \%$ \\
\hline 2017 & 2806426 & 39605 & 2289854 & 476967 & $1,41 \%$ & $81,59 \%$ & $17,00 \%$ \\
\hline 2018 & 4557447 & 75945 & 4024703 & 456799 & $1,67 \%$ & $88,31 \%$ & $10,02 \%$ \\
\hline 2019 & 6132097 & 86840 & 5524866 & 520391 & $1,42 \%$ & $90,10 \%$ & $8,49 \%$ \\
\hline \multicolumn{8}{|c|}{ Динаміка туристичного потоку } \\
\hline $\begin{array}{l}2019- \\
2000\end{array}$ & 4118099 & -291031 & 5239513 & -830383 & $-17,35 \%$ & $75,93 \%$ & $-58,58 \%$ \\
\hline $\begin{array}{l}2019- \\
2010\end{array}$ & 3851340 & -248995 & 4229243 & -128908 & $-13,31 \%$ & $33,29 \%$ & $-19,98 \%$ \\
\hline $\begin{array}{l}2019- \\
2015\end{array}$ & 4112521 & 71681 & 3877476 & 163364 & $0,67 \%$ & $8,53 \%$ & $-9,19 \%$ \\
\hline $\begin{array}{l}2019- \\
2018\end{array}$ & 1574650 & 10895 & 1500163 & 63592 & $-0,25 \%$ & $1,79 \%$ & $-1,54 \%$ \\
\hline
\end{tabular}

\footnotetext{
${ }^{1}$ Державна служба статистики України (2020). Головна сторінка <http://www.ukrstat.gov.ua> (2020, вересень, 15).
} 


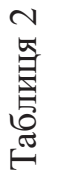

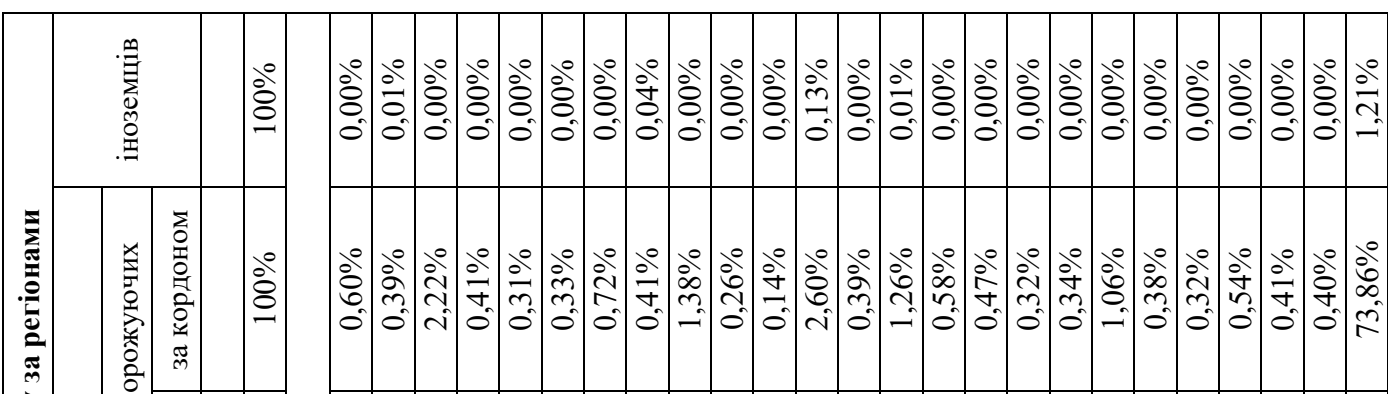

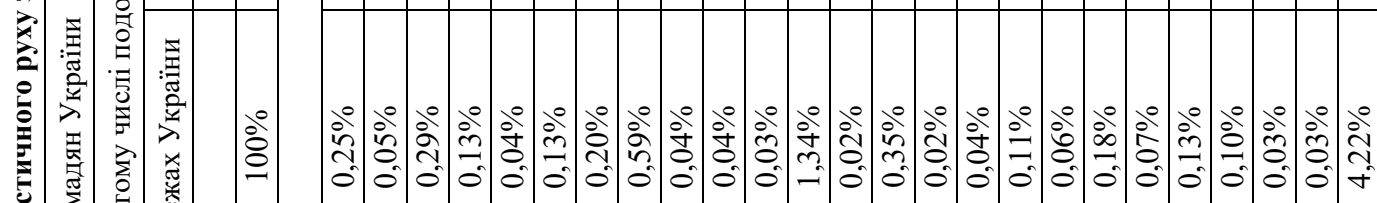

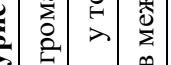

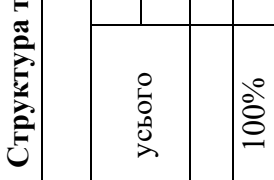

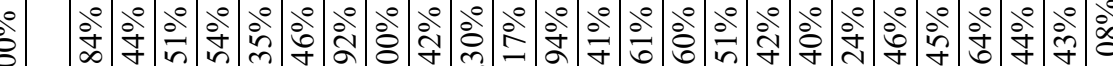

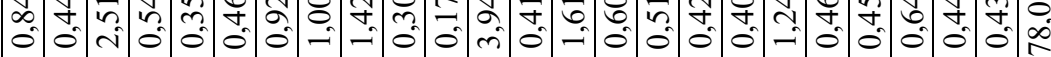

|

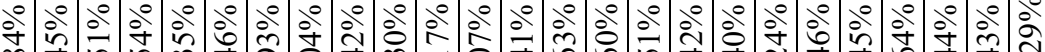

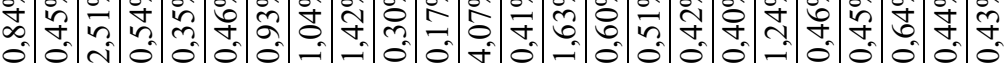

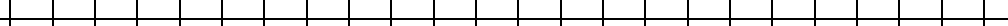

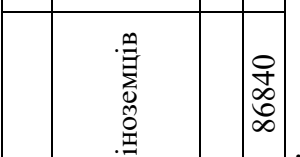

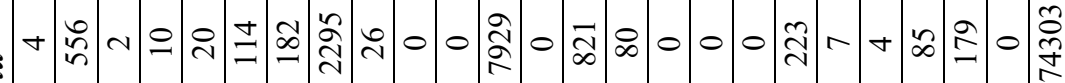



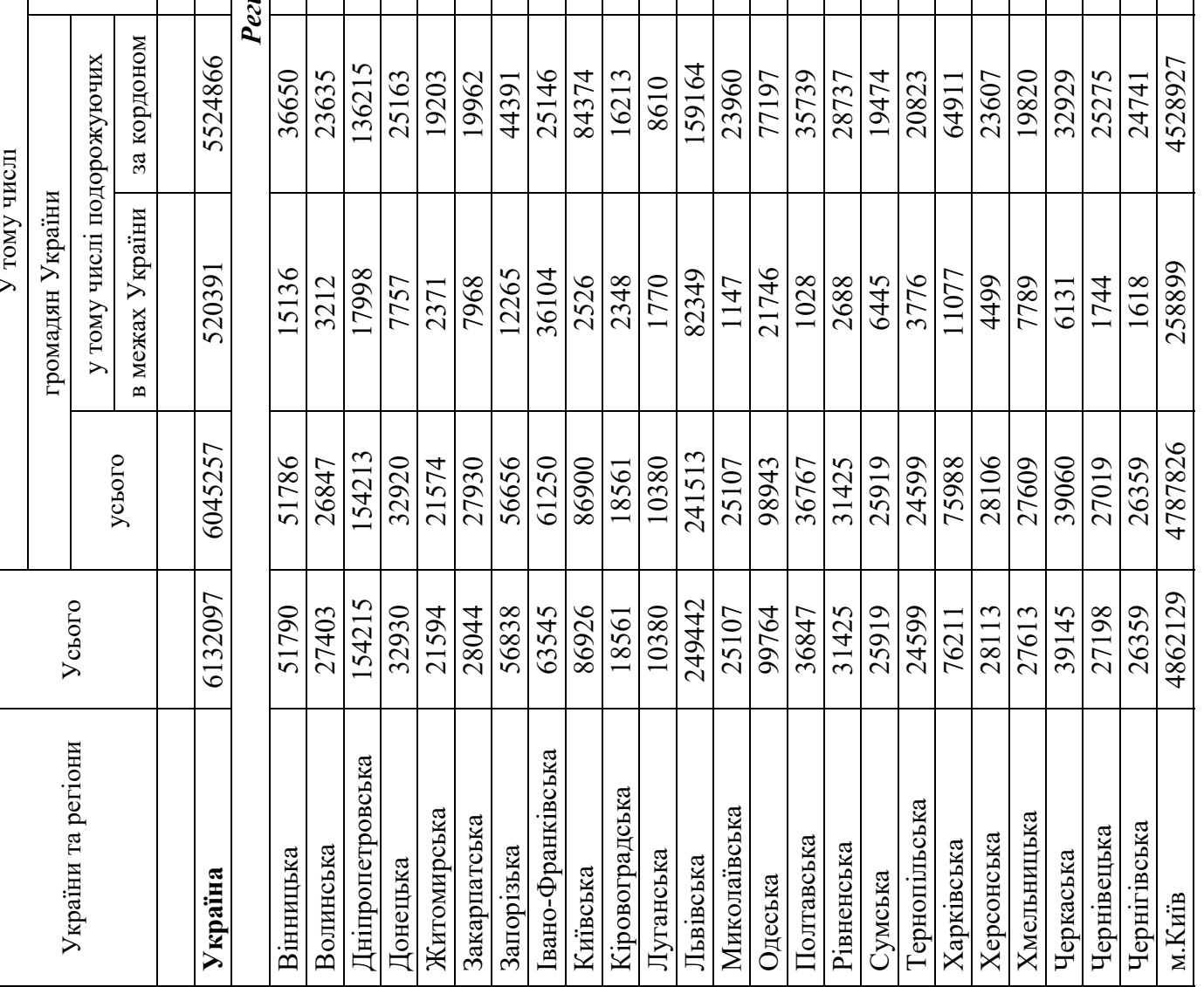

${ }^{1}$ Державна служба статистики України (2020). Головна сторінка $<\mathrm{http}: / / w w w . u k r s t a t . g o v . u a>$ (2020, вересень, 15). 


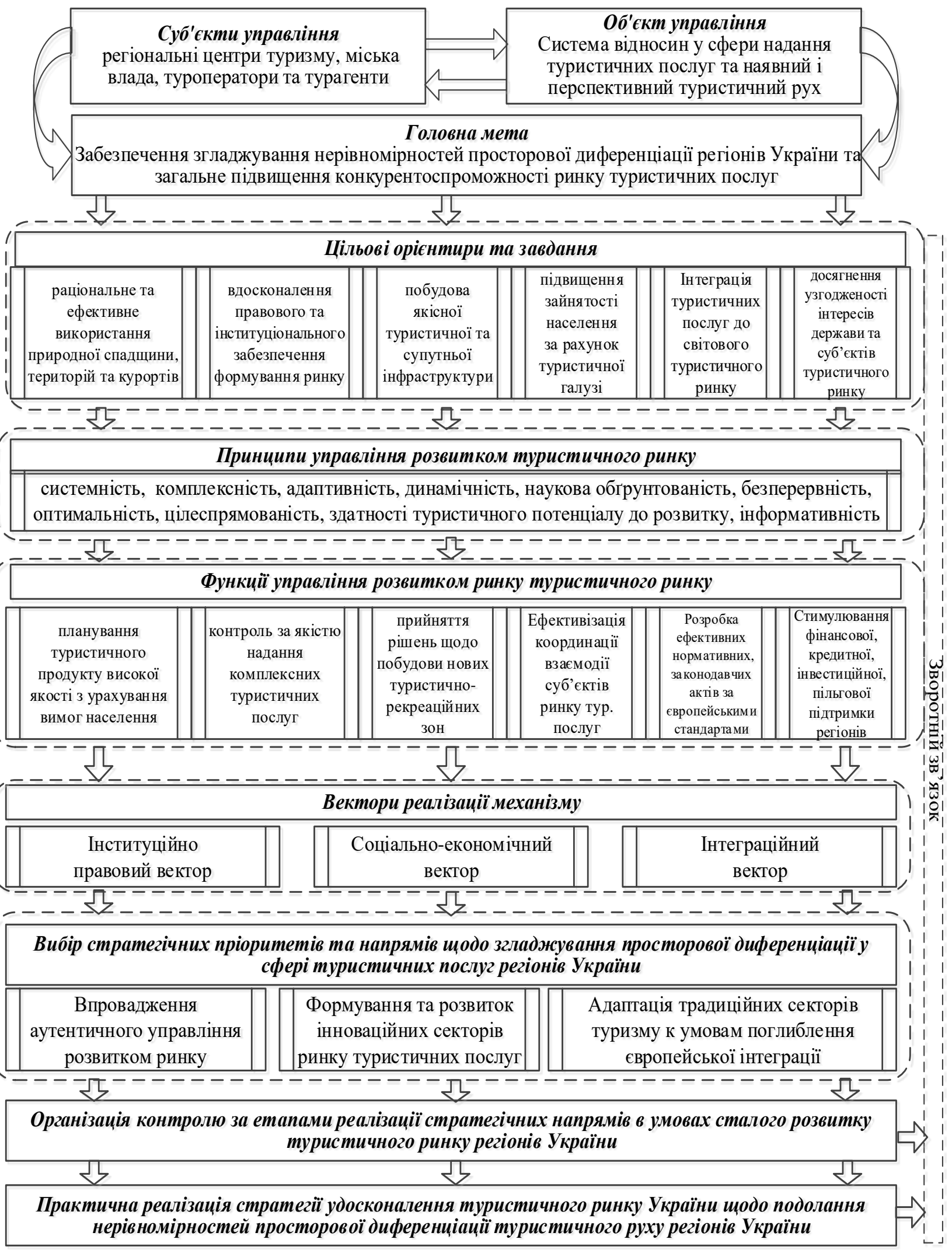

\section{Рис. 2. Механізм ефективного управління туристичною діяльністю регіонів України ${ }^{1}$}

\footnotetext{
${ }^{1}$ Рега, М. В. (2009). Туристичний бізнес в економічному просторі України. Теоретичні та прикладні питання економіки, 19, 299-303.
} 
Досягнення мети механізму досягається через вирішення цільових орієнтирів та завдань управління розвитком, а саме:

1. Раціональне та ефективне використання природної спадщини, територій та курортів дозволить впровадити передовий досвід стійкого розвитку туристичного сектору, забезпечить фінансову та технологічну підтримку, дозволить розробити інноваційні проекти та передові практики розвитку туристичного ринку регіонів, а також зберегти екосистеми та культурну спадщину.

2. Вдосконалення правового та інституціонального забезпечення формування ринку дозволить забезпечити законодавчої гарантії та дієві механізмів державної політики сприяння та підтримки розвитку туристичних підприємств регіонів України

3. Побудова якісної туристичної та супутньої інфраструктури із врахуванням просторової нерівномірності розвитку та диференціації економічного простору.

4. Підвищення зайнятості населення за рахунок туристичної галузі несе важливу соціальноекономічну функцію для держави в цілому, та особливої важливості набуває для депресивних регіонів України

5. Інтеграція туристичних послуг до світового туристичного ринку за допомогою слідування сучасним тенденціям міжнародного туризму (транснаціоналізації, глобалізації, кластерізації тощо).

6. Досягнення узгодженості інтересів держави та суб'єктів туристичного ринку здійснюється за допомогою впровадження ефективної моделі державного регулювання та сприяння розвитку підприємницьких процесів у туристичній галузі.

Функціонування механізму ефективного управління туристичною діяльністю регіонів України повинен базуватися на наступних принципах:

- системності - управління туристичною діяльністю є багатоскладовою, цілісною, відкритодинамічною системою 3 безліччю елементів, які, взаємодіють один 3 іншим, та 3 наявним мікросередовищем та макросередовищем;

2) комплексності- розроблений підсистема повинен мати відповідний набір базових комплексних показників, які у подальшому можуть використовуватися на усіх етапах туристичної діяльності;

3) адаптивності - можливість адаптації розробленого механізму під відповідні умови, в яких здійснює свою діяльність туристичні компанії окремого регіону та мати значну гнучкість реагування на внутрішні та зовнішніх зміни цих умов;

4) динамічності -постійний розвиток туристично-рекреаційної діяльності регіонів є запорукою успішності подолання наявної просторової диференціації;

5) безперервності -означає постійне нарощування туристичного потенціалу регіонів для підвищення конкурентоспроможності у довгостроковому періоді;

6) цілеспрямованості - полягає у спрямовуванні туристичної діяльності регіонів на досягнення загальних цілей та згладжування просторової диференціації;

7) оптимальності- означає, що усі рішення при створенні, розробці та впроваджені туристичного продукту мають бути найкращими за вибраними цільовими орієнтирами та стратегічними напрямками розвитку;

8) наукової обгрунтованості - підвищення туристичних потоків у регіонах неможливо без впровадження новітніх та сучасних технологій, які базуються на наукових дослідженнях та розробках;

9) інформативності - забезпечення повною та багатокритеріальною інформацією про усі сфери туристичної діяльності регіонів.

Вектори реалізації механізму нерозривно пов'язані з функціями управління розвитком ринку туристичного ринку та мають собі на меті:

1. Інституційно-правовий вектор - створення універсальної інституційно-законодавчої основи розвитку ринку туристичних послуг, яка відповідає світовим та європейським стандартам забезпечення якості його функціонування.

2. Соціально-економічний вектор - виконання соціальної функції держави шляхом підвищення кількості робочих місць у сфері туризму та обслуговування туристично-рекреаційних об'єктів за рахунок чого підвищується грошові надходження до бюджетів різних рівнів.

3. Інтеграційний вектор - використання міжнанаціональної взаємодії у сфері туризму для зміцнення взаєморозуміння і довіри між країнами в різних сферах їх життєдіяльності. 
Найважливішим у розробленому механізмі ефективного управління туристичною діяльністю регіонів України $є$ вибір стратегічних пріоритетів та напрямів щодо згладжування просторової диференціації у сфері туристичних послуг регіонів України, а саме:

1. Впровадження аутентичного управління розвитком ринку - основана на на урахуванні наявних специфічних туристичних можливостей регіональних ринків. Це управління можливо здійснювати на засадах врахування асиметричності інфраструктурного розвитку регіональних ринків та просторової диференціації розміщення формуючих ринок факторів. Ефективне аутентичного управління дозволить підвищити темпи фінансово-економічного зростання та скоротити нерівність та бідність серед населення регіонів України через використання регіонально-туристичних конкурентних переваг.

2. Формування та розвиток інноваційних секторів ринку туристичних послуг - включає в себе впровадження сучасних видів туризму (сільського, зеленого, індустріального); відновлення занедбаної туристичної спадщини-(замків, фортець, палаців); запровадження національних програм підвищення інтересу громадян до культури України, історії та сучасності рідного регіону, підвищення туристичного іміджу держави серед іноземців на регіональному рівні.

3. Адаптація традиційних секторів туризму к умовам поглиблення європейської інтеграції має здійснюватися із урахуванням визначених на міжнародному ринку туристичних послуг світових та європейських стандартів обслуговування туристів.

Треба також відзначити, що важливе місце в розробленому механізмі (рис. 2) належить система організації контролю за етапами реалізації стратегічних напрямів в умовах сталого розвитку туристичного ринку регіонів України, яка має зворотній зв' язок з іншими підсистемами механізму та забезпечує стале практичне виконання усіх його теоретико-методичних засад.

\section{Висновки та перспективи подальших досліджень.}

У наведеному досліджені проблем просторової диференціації туристичного руху регіонів України були отримані наступні теоретичні та практичні результати:

1 Визначено наявність та теоретичне обгрунтування туристичного руху на різних стадія розвитку ринку туристичних послуг.

2 Узагальнена та систематизована категорія «просторова диференціація» та визначено, що у сфері туризму ця категорія означає нерівномірність розвитку ринку туристичних послуг, яку викликано значимими відмінностями в розподілі природних ресурсів, кліматичними особливостями регіонів, культурно-історичною обумовленістю міст та областей, нерівномірним розміщенням транспортної, комунікаційної, курортно-розважальної інфраструктури та диспропорцією розподілу рекреаційних ресурсів.

3 Проведено аналіз туристичного руху як України в цілому за період 2000-2019, так й по окремим регіонам за 2019 р. та виявлено, що проблема просторої нерівномірності розподілу туристичних ресурсів в регіонах України є значущою. «Центр» туризму України складають лише $20 \%$ від усіх наявних регіонів України. Інші 80 \% областей складають периферію.

4 Виходячи із визначеної в аналізі значної просторової диференціації регіонів України було розроблено механізм ефективного управління туристичною діяльністю регіонів України, який, у разі його успішного реалізації на практики, допоможіть згладити нерівності туристичного розвитку регіонів та підвищити загальний кількісті та якісні показники туризму України.

Практичне значення одержаних результатів полягає в тому, що вони можуть бути теоретикометодичною основою для подальшого дослідження проблем згладжування просторової диференціації туристичного руху регіонів України.

\section{References:}

1. Reha, M. (2009) Turystychnyi biznes v ekonomichnomu prostori Ukrainy [Tourism business in the economic space of Ukraine]. Teoretychni ta prykladni pytannia ekonomiky [Theoretical and applied issues of economics], 19, 299-303 [in Ukrainian].

2. Parshyn, Yu. (2014) Otsinka nerivnomirnosti ekonomichnoho rozvytku za indykatoramy poliaryzatsii ta asymetrii [Estimation of uneven economic development on indicators of polarization and asymmetry]. Investytsii: praktyka ta dosvid [Investments: practice and experience], 24, 28-33 [in Ukrainian].

3. Jekova, V. (2013) Identifikatsiia obieektov prostranstvennogo menedzhmenta v regione [Identification of objects of spatial management in the region]. Materialy mezhdunarodnoj nauchno-prakticheskoj konferencii Sovremennye napravlenija teoreticheskih i prikladnyh issledovanij 2013 [Proceedings of the international scientific-practical 
conference Modern areas of theoretical and applied research 2013]. <http://www.sworld.com.ua> (2020, September, 15). [in Russian].

4. Shkromada, V. I. (2013). Sovershenstvovaniye nalogovykh instrumentov sglazhivaniya sotsial'no-ekonomicheskoy polyarizatsii regionov [Improving tax instruments for smoothing the socio-economic polarization of regions]: avtoreferat dissertatsii na soiskaniye nauchnoy stepeni kandidata ekonomicheskikh nauk [thesis abstract for the degree of candidate of economic sciences]. Belgorod: FGAOU VPO Belgorod State National Research University. [in Russian].

5. Soroka, I. (2012) Suchasni tendentsii mizhnarodnoho rynku turystychnykh posluh [Current trends in the international market of tourist services]. Aktualni problemy mizhnarodnykh vidnosyn [Current issues of international relations], 111, 266-273 [in Ukrainian].

6. Tarasenok, A. (2014). Geoeconomic mechanism for ensuring the competitiveness of a tourist destination [Geoekonomicheskiy mekhanizm obespecheniya konkurentosposobnosti turisticheskoy destinatsii]. Minsk: RIPO. [in Russian].

7. Zynoveva, A. (2011). Problemy sglazhivaniia prostranstvennoi poliarizatsii v ekonomike regionov [Problems of smoothing spatial polarization in the regional economy]. Problemy sovremennoi ekonomiki [Problems of the modern economy], 4, 256-259. [in Russian].

8. Krugman, P. (1991) Geography and Trade. Cambridge: MA: MIT Press [in English].

9. Derzhavna sluzhba statystyky Ukrayiny (2020) [State Statistics Service of Ukraine (2020)]. Holovna storinka [Homepage]. <http://www.ukrstat.gov.ua> (2020, September, 15). [in Ukrainian]. 